\title{
Annual Meeting of A.O.U., 1959
}

\section{By John A. Livingston, Executive Director, Audubon Society of Canada}

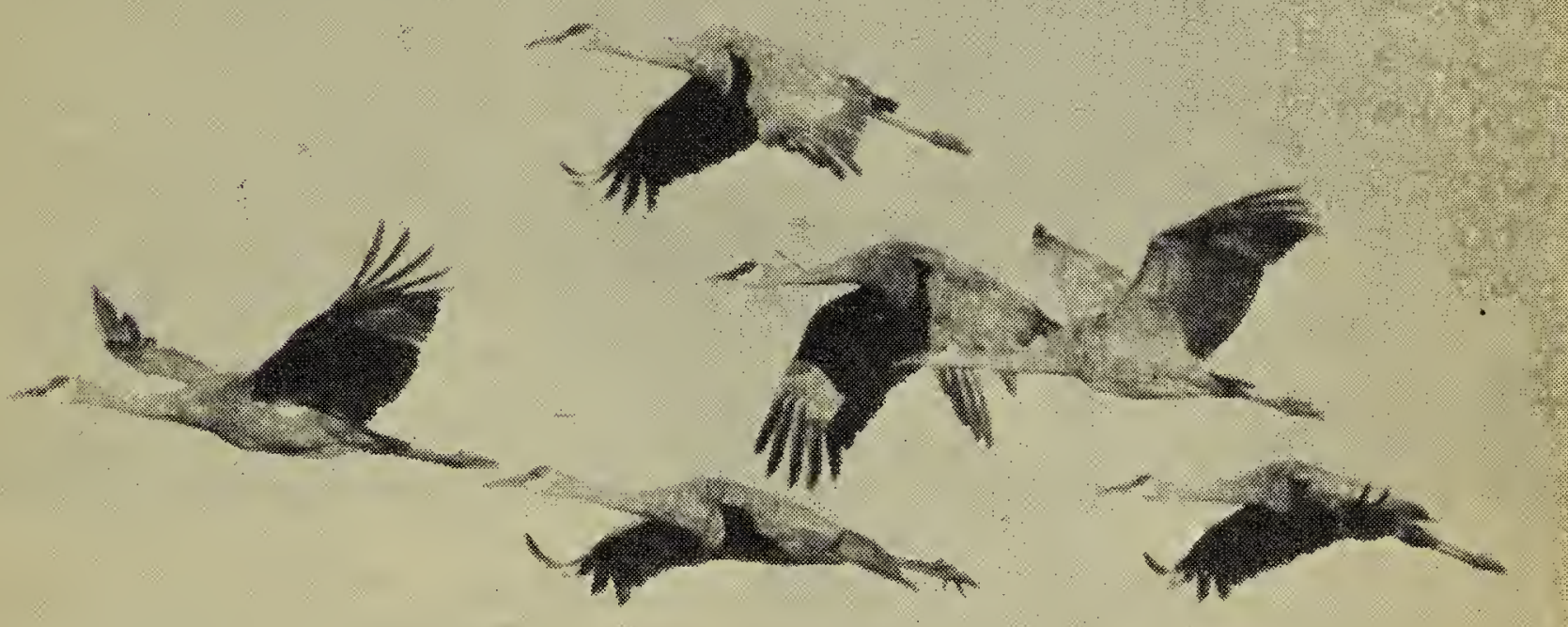

"This alone was worth coming 4,500 miles to see!" James Fisher sprawled on his ample back in the prairie stubble, gazing skyward, entranced. Above him in the late summer sunshine, hundreds of sandhill cranes were wreeling effortlessly, riding invisible thermals beneath anvil-shaped cumulus clouds. Higher and higher the great birds mounted the spiral stairways of the air, until many literally rose out of sight. ...

Fisher was by no means the sole observer of this magnificent spectacle. Around and near him were scores of enthusiastic bird students, all spellbound by a phenomenon relatively few had ever witnessed before. 'It was Saturday, August 29, 1959. The place was the north end of Last Mountain Lake, Saskatchewan. The milling crowd (which despite its size for once did not outnumber the birds) were participants in a field trip portion of the 77th annual meeting of the American Ornithologists' Union, first such meeting ever held in western Canada.

As the late Ludlow Griscom might have said, the world is full of people who have not seen trousands of sandhill cranes in the air at once. As Stuart Houston did say, "It's indescribable." One of the most spec. tacular natural events of the Canadian year unfolded-right on schedule-for the delight and edification of people who had come thousands of miles to the most memorable and rewarding A.O.U. meeting in recent history. I say "right on schedule." I almost said "right on cue."

It was not mere blind luck that the cranes-the feature attraction of an altogether remarkable series of field trips-picked up their cue. It was good management and careful preparation, albeit delicately blended with that mysterious good fortune 
that often seems to smile on the deserving! The several local committees responsible for the various arrangements have no doubt been listed elsewhere, but I must make special mention of the keen types with their trucks and their two-way radios, wro scoured the feeding areas of the cranes and kept play-by-play tabs on their location. The secret's out. Anyone who has ever had any.thing to do with birds tries to leave as little as possible to chance!

There's no end to the memories of that delightful afternoon. There were the determined but unavailing efforts of Roger Peterson and myself (with generous aid from Elmer Fox, Frank Brazier, et al) to produce sharp-tailed grouse for James Fisher's life list. That sharptails were spotted later in the day availed us little. By that time we were back looking for Baird's sparrows - for R. T. P. Memorable, too, was that seemingly endless, happy and lighthearted queue waiting for lunch at Last Mountain Lake. A lunch, by the way, well worth queueing for. ...

There was the breathtaking stoop of a prairie falcon, the ponderous but

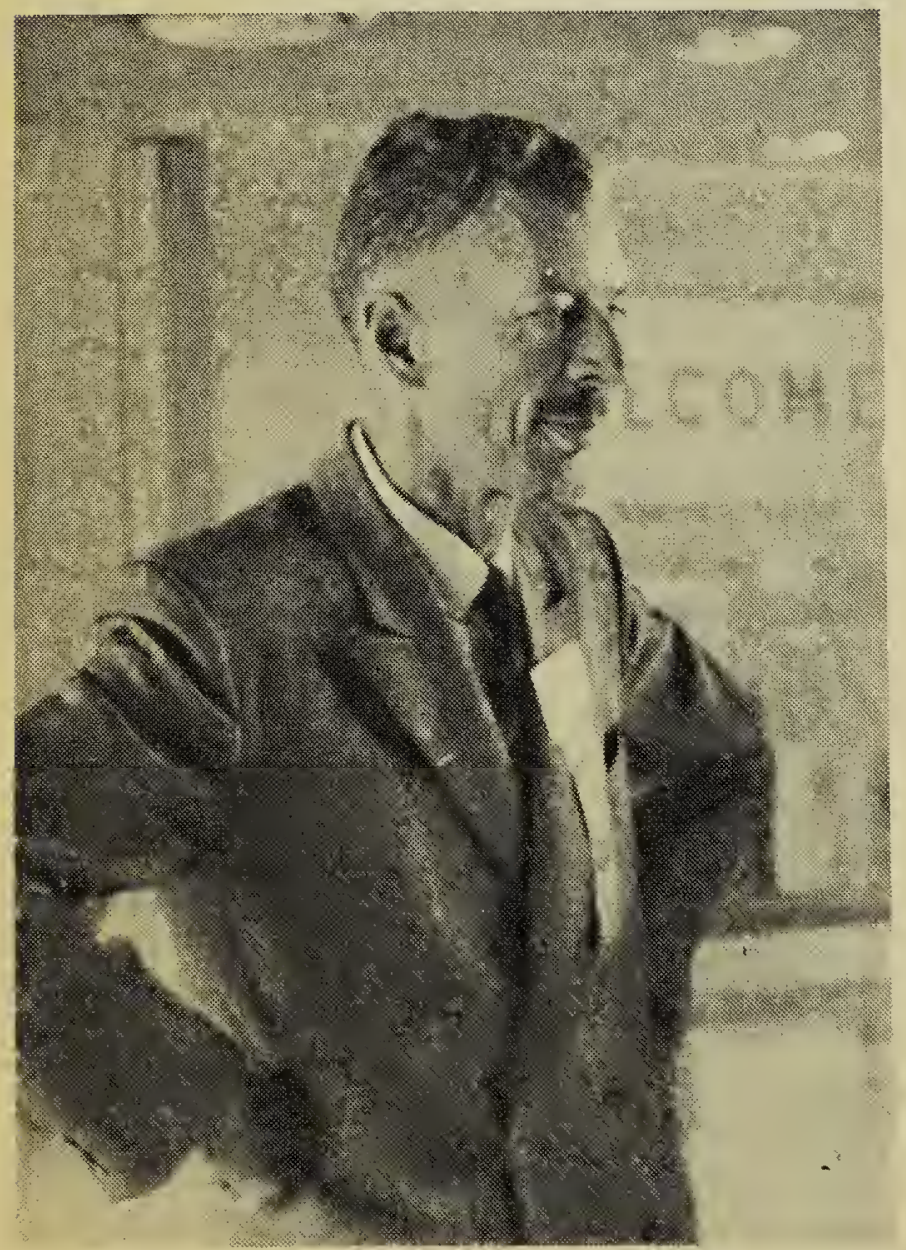

Photo by $F$. W. Kent

BILL GUNN

author of the "Sounds of Nature" series of bird records. ultra-dignified flapping of a pelican the chattering of the longspurs, the guttural resonance of cranes, the dry rustling of the prairie breeze in the aspens and dwarf willows. There were the miniature explosions of Sprague's pipits and horned larks rising from the grass in front of us. But best of all, to me, there was that fabulous western sky....

The Regina meeting of the A.O.U. was not held entirely in the open, though picnic supper on the Museum lawn, a falconry demonstration by Dick Fyfe, and sundry other fresh-air endeavors reflected the desire of our hosts to expose us to their exhilarating outdoors at every conceivable excuse. Indoors, the pattern of careful, thoughtful arrangement, painstaking attention to detail, and unusually imaginative presentation gave one a feeling less of attending a formal convention, more of visiting old friends.

It is not my purpose to mention the many papers delivered at the meeting. These will be published, no doubt, in due course. It is my intention, however, to pay tribute to those responsible for the art and photo-

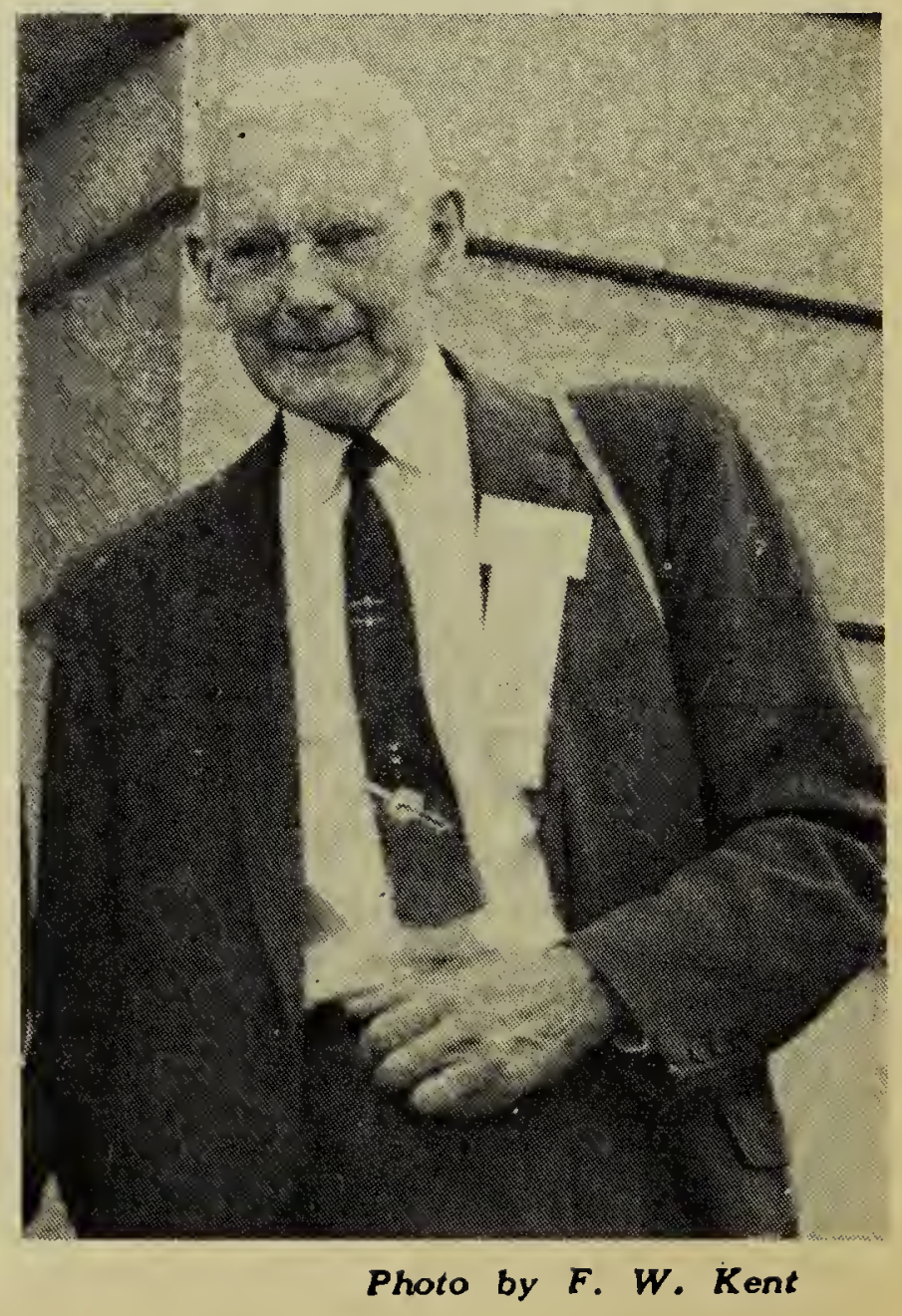

ALEXANDER WETMORE dean of American ornithology. 


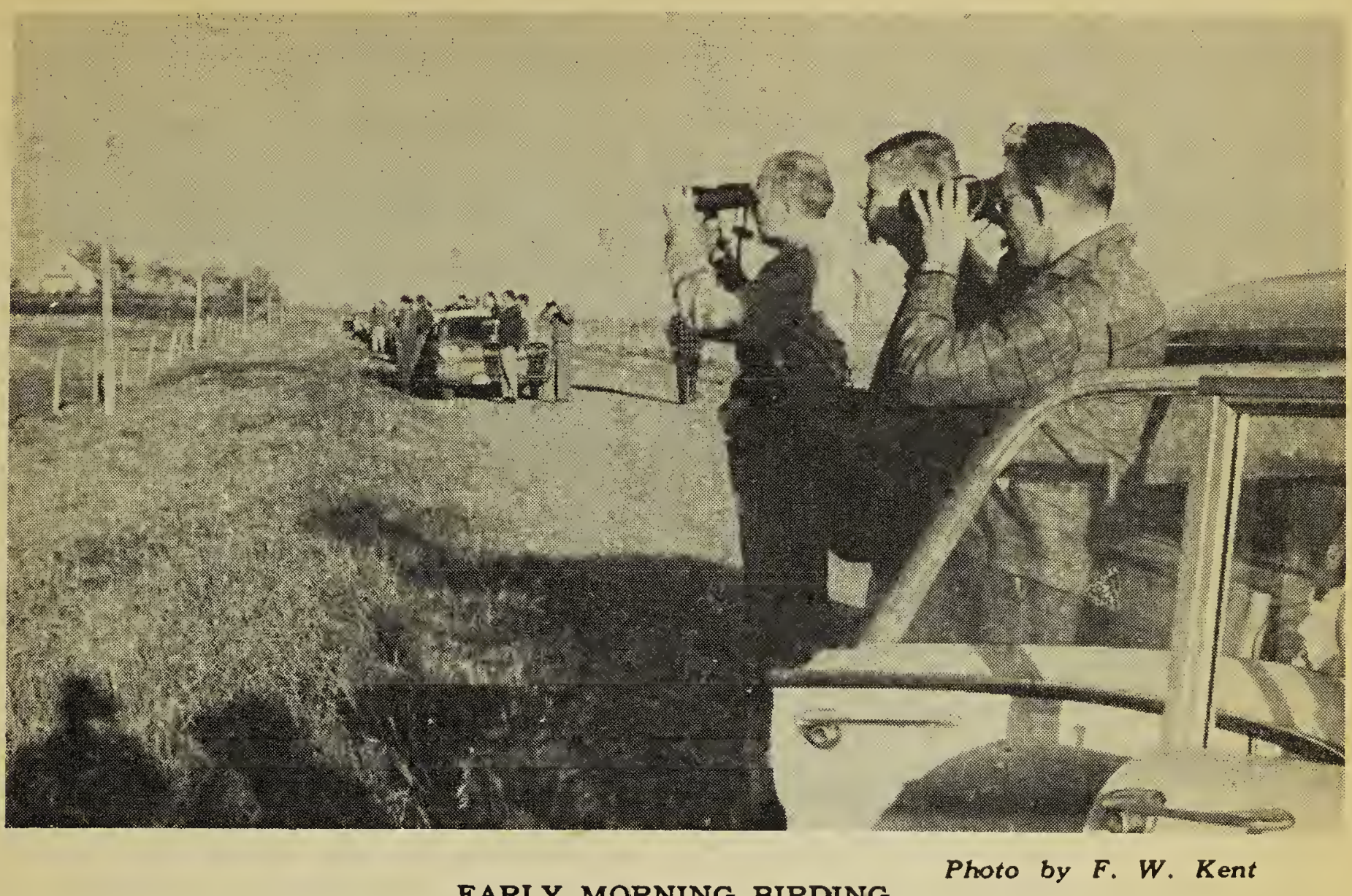

EARLY MORNING BIRDING

graphy exribits, the latter in particular being by all odds the finest presentation of this sort of material I have ever seen anywhere. It will unquestionably serve as a model for such displays elsewhere. It was much more than a collection of firstclass photographs. It was an intimate, sensitive and wholly delightful introduction to the birds of Saskatchewan-or to birds everywhere. The incredibly versatile Fred Lahrman and the indefatigable and resourceful Bob Nero were doubtless the authors of this piece, which bore an unmistakable stamp of freshness and originality.

This same aura of youthful vigor and enthusiasm pervaded the entire proceedings. And what better habitat for the A.O.U. than the spankingnew Saskatchewan Museum of Natural History! Eyes were opened, unquestionably, and last impressions made, by this handsome, modern and vital building. Ideas were exchanged, theories expounded, opinions bandied, experiences swapped-all in an atmosphere of brightness, comfort and efficiency.

Mention cannot be made of the Museum without our remembering the one deeply regrettable part of the A.O.U. meeting. That, of course, was the unavoidable absence (through illness) of our good friend Fred Bard, the Museum's director and thus one of our chief rosts. To a man, those present keenly regretted not being able to shake Fred's hand and congratulate him-not only on his distinguished new building, but on his and the Museum staff's handling of their share of the intricate and multitudinous details of the meeting. If it is any consolation to him, all of us missed Fred Bard very greatly indeed. One certain consolation, however, must rave been the unique honor he enjoyed earlier this year, when he conducted Her Majesty the Queen on a tour of the Museum.

It's difficult to give adequate acknowledgment to the magnificent job Regina did on the A.O.U. convention. Of course it went well beyond the Regina Natural History Society, the whole province being involved through the Saskatchewan Natural History Society and the provincial government (the generosity of the latter being unprecedented in ornithological memory). The entire affair was a masterpiece of arrangement and presentation. Such a precedent will be difficult for local committees at subsequent meetings to equal. 